\title{
Effect of bisphosphonate treatment in osteogenesis imperfecta children in Cipto Mangunkusumo Hospital Jakarta
}

\author{
Aman Pulungan ${ }^{1,2,3^{*}}$, Jose Batubara ${ }^{1,2,3}$, Bambang Tridjaja ${ }^{1,2,3}$, Frida Soesanti ${ }^{1,2,3}$, Margaret Zacharin ${ }^{4}$, Putri Alevia ${ }^{1,2}$, \\ Dwi Lestari Pramesti ${ }^{1}$
}

From 8th APPES Biennial Scientific Meeting

Darwin, Australia. 29 October - 1 November 2014

\section{Background}

Bisphosphonates are the mainstay of pharmacologic fracture-prevention therapy for most forms of osteogenesis imperfecta (OI). Studies suggests that bisphosphonate treatment may significantly improve the natural history of all type of OI, particularly by decreasing the rate of fracture, increasing bone mineral density, decreasing bone pain, and significantly increasing height.

\section{Objective}

To evaluate the effect of bisphosphonate treatment in OI children treated in Cipto Mangunkusumo Hospital $(\mathrm{CMH})$ Jakarta.

\section{Method}

We retrospectively studied the data of age, gender, age at diagnosis, bisphosphonate treatment, and its effects in OI patients in $\mathrm{CMH}$ from Indonesian OI children registry, which is documented from January 2012 to May 2014.

\section{Results}

Seventy-seven OI cases (39 male), which were diagnosed at the age of 1 - 9 years old were recorded. Five patients underwent surgery and three patients died before commencing treatment. Nine patients received intravenous pamidronate and sixteen patients received zolendronic acid therapy. Liver and renal functions, as well as serum electrolyte levels were evaluated before and after treatment. Eight patients reported hyperthermia and three others experienced fatigue, bone pain, and abdominal

University of Indonesia, Jakarta, Indonesia

Full list of author information is available at the end of the article pain within 24 hours of therapy. Serum calcium level decreased in eight patients. No serious adverse effects were documented.

\section{Conclusions}

All registered OI cases patients that received bisphosphonates treatment showed no serious adverse effects.

\section{Authors' details}

${ }^{1}$ University of Indonesia, Jakarta, Indonesia. ${ }^{2}$ Cipto Mangunkusumo Hospital, Jakarta, Indonesia. ${ }^{3}$ Indonesia Pediatric Society, Jakarta, Indonesia. ${ }^{4}$ Royal Children's Hospital, Melbourne, Australia.

Published: 28 April 2015

doi:10.1186/1687-9856-2015-S1-P61

Cite this article as: Pulungan et al:: Effect of bisphosphonate treatment in osteogenesis imperfecta children in Cipto Mangunkusumo Hospital Jakarta. International Journal of Pediatric Endocrinology 2015 2015(Suppl 1): P61

Submit your next manuscript to BioMed Central and take full advantage of:

- Convenient online submission

- Thorough peer review

- No space constraints or color figure charges

- Immediate publication on acceptance

- Inclusion in PubMed, CAS, Scopus and Google Scholar

- Research which is freely available for redistribution

Submit your manuscript at www.biomedcentral.com/submit 